DOI: 10.17707/AgricultForest.62.4.27

\author{
Mykola NAZARENKO, Mykola KHARYTONOV ${ }^{1}$
}

\title{
CHARACTERISATION OF WHEAT MUTAGEN DEPRESSION AFTER GAMMA-RAYS IRRADIATED
}

\begin{abstract}
SUMMARY
Here we report cytogenetic, plant growth and development characteristics of mutation induction variability of the new wheat varieties and some relationships between means of cytogenetic characteristics and different doses and types of mutagens. The strategy of investigation combined the identification of genotypes carrying specific low-sensitive to mutagen factor using cytological and morphometrical analyzes screening of mutagen treated wheat populations with the approach of comparing different varieties by breeding methods to reveal its connections and differences, specific sensitive to mutagens effects on cell and plant level. The main purposes of investigations in this area were determination of the mutagen-polluted area suitability for agriculture; determination more suitable varieties for planting on mutagen-polluted area or as a object for mutation breeding.
\end{abstract}

Keywords: mutagen depression, winter wheat, gamma-rays, chromosomal aberrations

\section{INTRODUCTION}

There are three reasons for the study of plant mutant generation M1 after mutagenic effect. The first one is the determination of the mutagen-polluted area suitability for agriculture. More than $70 \%$ of soil in Ukraine used for agriculture is constantly exposed to chemical and physical mutagens. The second reason is the fact that the amount of material, obtained from the first generation, limits the opportunities of mutation breeding programmes (especially using the lethal doses). Wheat is the top food crop in Ukraine as well as in the whole world and the biggest part of grain is obtained primarily from winter wheat. The total area for winter wheat cultivation in Ukraine covers $6.8 \mathrm{mln}$. ha with actual productivity of $24 \mathrm{mln}$. tons and average capacity of $2.8 \mathrm{t} / \mathrm{ha}$. The third reason is the use of obtained M1 population to extract valuable mutant strains in further generations. Mutagenesis reduces plant growth and other crop yield structure components, increases the pollen sterility and cuts the germination and survival abilities of plants by means of chemical agents and gamma rays; sometimes the great part of population is killed with the critical doses (Solanki, Sharma, 2000). Depression increases with the increase of dose (Yilmaz, Erkan, 2006).

\footnotetext{
${ }^{1}$ Mykola Nazarenko, (corresponding author: envteam@ukr.net), Mykola Kharytonov, Department of Plant Breeding and Seeds Management, Faculty of Agronomy, Dnipropetrovsk State Agrarian and Economic University, 49600,Dnipro, UKRAINE.

Notes: The authors declare that they have no conflicts of interest. Authorship Form signed online.
} 
But sometimes we observe stimulating effect (in case of low doses) or absence of depression (at medium concentrations of some chemical mutagens) (Subudhi et al, 1992). In first generations for wheat as cultivar composed from three genomes we observed only some dominant. Positive desirable mutant will be selected and be incorporated in future breeding programs (Ali Sakin et al, 2005).

Mutagenic effects of chemicals or ionizing radiation have been assessed by analysis of chromosomal aberrations (Rakhmatullina and Sanamyan, 2007). Chromosomal abnormalities in irradiated mitotic cells range from breaks, through exchanges, laggards and anaphase bridges, dicentric and centric ring formations, terminal fragments with telomeric signal at only one end and interstitial fragments that appear as double minutes without any telomeric signals (Rakhmatullina and Sanamyan, 2007).

Mutated plants typically show reduced fertility, mainly caused by chromosomal rearrangements and genomic mutations during meiosis. For crops like wheat, individual tillers (side branches) originate from different cells of the embryo of the treated seeds. If an aberration occurs in one of these cells, it will be carried in the tiller developed from that cell (Hossain and Alam, 2001; Huaili et al, 2005; Shu et al, 2011).

Analysis of chromosomal aberrations after mutagen action of any kind of mutagen by meto-anaphases method is one of the most precision methods which we can be used for determine fact of mutagen action on plants, identify nature of mutagen factor (Lifang et al; 2001, Adlera et al, 2004; Özel et al, 2015; Ukai, 2006, Waugha. 2006). Usually, analysis are widely used as for radionuclide's pollution of environment and its level (Korogodina et al, 1998), danger of this pollution (Geraskin et al, 2002) as for determine optimal doses of radiation and chemical agents in breeding work with plant material (Ahloowalia et al, 2004; Nazarenko, 2015). However, this compound exhibits high mutagenic, clastogenic and recombinational activity in plants, frequently stronger than that of the most powerful alkylating agents (Grant and Owens, 2001). A correlation between "clastogenic adaptation" expressed as a reduction of chromatid type aberrations, micro-nuclei and aneuploid cells, and the "clastogenic adaptation" has been shown (Bignold, 2009). We have next reasons for the study of chromosomes changes after mutagenic treatment: the determination of the mutagen-polluted area suitability for agriculture, correlation between aberrations and visible mutations in next generations (for mutation breeding purposes) and for identifying fact of mutagen action and its nature. Advantages of the method are promptness, objectivity of the results, the reliability and the ability to assess the impact of integrated wide variety of mutagens by nature (van Harten, 1998; Karthika and Subba, 2006; Albokari, 2014).

The main purposes of investigations in this area were determination of the mutagen-polluted area suitability for agriculture; determination more suitable varieties for planting on mutagen-polluted area or as a object for mutation breeding. 


\section{MATERIAL AND METHODS}

Dried seeds (approx. 14\% moisture content) of (in brackets method of obtaining varieties or used mutagens) Favoritka, Lasunya, Hurtovina (irradiation of initial material by gamma rays), line 418, Kolos Mironovschiny (field hybridization), Sonechko (chemical mutagenesis, nitrosodimethilurea (NDMU) $0.005 \%$ ) and Kalinova (chemical mutagenesis, DAB 0.1\%), Voloshkova (termomutagenesis - low plus temperature under vernalizaion has been used as mutagen factor) of winter wheat (Triticum aestivum L.) were subjected to 100,150, 200, 250 Gy gamma irradiation. Each treatment was comprised of 1000 wheat seeds. These doses are optimal for the breeding process that has been repeatedly established earlier (Ahloowalia et al, 2004; Nazarenko, 2015). Nontreated varieties were used as a check.

Treated seeds were grown in rows with inter and intra-row spacing of 50 and $30 \mathrm{~cm}$, respectively, to raise the M1 population.

The untreated seeds of mother varieties (parental line/variety) were also planted after every ten rows as control for comparison with the M1 population. M1 plant rows were grown in three replications with check-rows of untreated varieties in every ten-row interval. Data on seed germination and surviving plants were recorded considering whole plots of M1 population. Data on yield structure components (plant height, general number of culms, number of productive culms, spike length, spikelets per spike, number of grain per spike, grain weight per spike and plant, 1000 grains weight) were taken from 50 randomly selected plants of each treatment representing more or less all types of morphological plants.

The seeds used in this study were of the M0 generation. After mutagen treatment dry seeds were germinated in Petri dishes under $24-72$ hours (depends on presoaking and mutagen action), temperature $+250 \mathrm{C}$. Afterwards central primary roots were cut and fixed in solution of alcohol and acetic acid (in proportion 3:1) for 24 hours. Fixation material was stored in $70 \%$ alcohol solution under temperature $2^{0} \mathrm{C}(20-25$ roots per variant $)$.

Cytological analysis was carried out by the standard method at temporary press-time preparations of root tips $(1-1.5 \mathrm{~mm}$ ) stained with acetocarmine (has been prepared by Remsderh).

Tissue maceration (if it needs for analysis) was carried out at $45 \%$ solution of acetic acid (during 5 minutes on bane-marie under 600C). Anaphase of cell division was observed by light microscope JNAVAL. No less than 800 cells in proper phases of mitosis were observed in each variant (Lifang et al, 2001; Rank et al, 2002, Natarajan, 2005).

Mathematical processing of the results was performed by the method of analysis of variance, the variability of the mean difference was evaluated by ANOVA, the grouping by the nature of mutagens was performed by cluster analysis (Euclidian distance) (Klekka, 1989).

Used the standard tools of the program Statistica 8.0 for cluster analysis (Multivariate Exploratory Techniques, cluster analysis, single linkage, Euclidian distance), factor analysis (Statistics 8.0, ANOVA module). 


\section{RESULTS AND DISCUSSION \\ Analysis of grows and development of plants.}

In M1 population, observations were recorded seed germination and plant surviving, pollen fertility, plant height, spikes/plant, spike length, kernels/spike, 1000 -grain weight, yield/plant (table $1-3)$. Standard error $( \pm$ SE) values of the treated populations are at tables too.

The results on germination of seeds, survival rate of plants derived from treated and untreated seeds are tabulated (Table 1). Germination and survival abilities of seeds reduce compared to untreated seeds of the initial variety in all cases. Plant survival ability ranges from 55 (Voloshkova) to 5.3\% (Sonechko) at $250 \mathrm{~Gy}$, while it ranged from 98 to $92 \%$ under untreated control.

As for the impact of gamma rays on the germination and survival abilities, it is the usual effect in plants for most crops previously observed by many researchers in wheat as well.

However, we can see that some varieties were statistically more successful in survivals ability.

Table 1. Main parameters of grown of winter wheat plants at M1 generation

\begin{tabular}{|c|c|c|c|c|}
\hline Trial & $\begin{array}{c}\text { Germination, } \\
\%\end{array}$ & $\begin{array}{c}\text { Survival } \\
\text { after winter, } \\
\%\end{array}$ & $\begin{array}{c}\text { Germination, } \\
\%\end{array}$ & $\begin{array}{c}\text { Survival } \\
\text { after winter, } \\
\%\end{array}$ \\
\hline Variety & \multicolumn{2}{|c|}{ Kolos Mironivschini } & \multicolumn{2}{|c|}{ Kalinova } \\
\hline Check & $98 \pm 0,57$ & $91 \pm 0,93$ & $94 \pm 0,94$ & $88 \pm 0,98$ \\
\hline gamma-rays, 100 Gy. & $79 \pm 0,76^{*}$ & $76 \pm 1,01 *$ & $75 \pm 1,07 *$ & $70 \pm 1,11 *$ \\
\hline gamma-rays, $150 \mathrm{~Gy}$ & $69 \pm 1,09 *$ & $66 \pm 1,13 *$ & $71 \pm 1,15^{*}$ & $66 \pm 1,18 *$ \\
\hline gamma-rays, $200 \mathrm{~Gy}$ & $58 \pm 1,48 *$ & $54 \pm 1,71 *$ & $47 \pm 1,24 *$ & $44 \pm 1,43 *$ \\
\hline gamma-rays, $250 \mathrm{~Gy}$ & $38 \pm 1,26^{*}$ & $36 \pm 1,34 *$ & $37 \pm 0,83^{*}$ & $35 \pm 1,10^{*}$ \\
\hline Variety & \multicolumn{2}{|c|}{ Voloshkova } & \multicolumn{2}{|c|}{ Sonechko } \\
\hline Check & $92 \pm 0,57$ & $87 \pm 0,93$ & $94 \pm 0,94$ & $89 \pm 0,98$ \\
\hline gamma-rays, $100 \mathrm{~Gy}$. & $73 \pm 0,76^{*}$ & $69 \pm 1,01 *$ & $65 \pm 0,57 *$ & $62 \pm 0,93 *$ \\
\hline gamma-rays, $150 \mathrm{~Gy}$ & $64 \pm 1,09 *$ & $60 \pm 1,13 *$ & $43 \pm 0,57 *$ & $40 \pm 0,93 *$ \\
\hline gamma-rays, $200 \mathrm{~Gy}$ & $55 \pm 1,26^{*}$ & $52 \pm 1,34^{*}$ & $31 \pm 1,14^{*}$ & $29 \pm 1,72 *$ \\
\hline gamma-rays, $250 \mathrm{~Gy}$ & $55 \pm 1,48$ & $51 \pm 1,71$ & $5,6 \pm 1,07 *$ & $5,3 \pm 1,39 *$ \\
\hline Variety & \multicolumn{2}{|c|}{ Favoritka } & \multicolumn{2}{|c|}{ Hurtovina } \\
\hline Check & $98 \pm 0,57$ & $91 \pm 0,93$ & $92 \pm 0,94$ & $84 \pm 0,98$ \\
\hline gamma-rays, $100 \mathrm{~Gy}$. & $82 \pm 0,76^{*}$ & $76 \pm 1,01 *$ & $73 \pm 1,07 *$ & $67 \pm 1,11 *$ \\
\hline gamma-rays, $150 \mathrm{~Gy}$ & $58 \pm 1,09 *$ & $54 \pm 1,13 *$ & $52 \pm 1,15^{*}$ & $48 \pm 1,18 *$ \\
\hline gamma-rays, $200 \mathrm{~Gy}$ & $49 \pm 1,26 *$ & $45 \pm 1,34 *$ & $55 \pm 0,83 *$ & $50 \pm 1,10 *$ \\
\hline gamma-rays, $250 \mathrm{~Gy}$ & $39 \pm 1,48 *$ & $36 \pm 1,71 *$ & $36 \pm 1,24 *$ & $33 \pm 1,43 *$ \\
\hline Variety & \multicolumn{2}{|c|}{ Lasunya } & \multicolumn{2}{|c|}{ Line 418} \\
\hline Check & $98 \pm 0,57$ & $94 \pm 0,93$ & $93 \pm 0,94$ & $92 \pm 0,98$ \\
\hline gamma-rays, $100 \mathrm{~Gy}$. & $54 \pm 0,76^{*}$ & $52 \pm 1,01^{*}$ & $74 \pm 1,07 *$ & $67 \pm 1,11^{*}$ \\
\hline gamma-rays, $150 \mathrm{~Gy}$ & $48 \pm 1,09 *$ & $46 \pm 1,13 *$ & $70 \pm 1,15^{*}$ & $55 \pm 1,18 *$ \\
\hline gamma-rays, $200 \mathrm{~Gy}$ & $42 \pm 1,26^{*}$ & $41 \pm 1,34^{*}$ & $48 \pm 1,24^{*}$ & $36 \pm 1,43^{*}$ \\
\hline gamma-rays, $250 \mathrm{~Gy}$ & $37 \pm 1,48^{*}$ & $35 \pm 1,71 *$ & $39 \pm 0,83^{*}$ & $35 \pm 1,10$ \\
\hline
\end{tabular}

$*$ - difference is statistically significance from check at $\mathrm{P}_{0.05}$ 
Table 2. Pollen fertility after mutagen action, $\%$

\begin{tabular}{|c|c|c|c|c|c|c|c|c|}
\hline Trial & 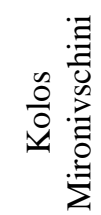 & 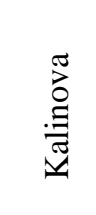 & $\begin{array}{l}\pi \\
0 \\
\frac{\pi}{7} \\
\frac{1}{0} \\
0 \\
0 \\
>\end{array}$ & 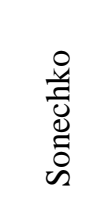 & 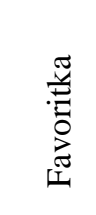 & 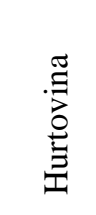 & 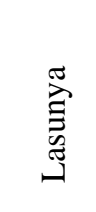 & 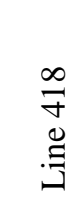 \\
\hline Check & 95,0 & 93,1 & 89,7 & 96,7 & 95,7 & 98,6 & 96,8 & 93,0 \\
\hline $\begin{array}{l}\text { gamma-rays, } \\
100 \mathrm{~Gy}\end{array}$ & $91,2 *$ & $82,9 *$ & $81,3^{*}$ & $84,5^{*}$ & $79,9 *$ & $82,3 *$ & $84,8 *$ & $89,1 *$ \\
\hline $\begin{array}{l}\text { gamma-rays, } \\
150 \mathrm{~Gy}\end{array}$ & $82,7 *$ & $74,6^{*}$ & $74,5^{*}$ & $70,9 *$ & $64,7 *$ & $67,8^{*}$ & $71,2 *$ & $81,6^{*}$ \\
\hline $\begin{array}{l}\text { gamma-rays, } \\
200 \text { Gy }\end{array}$ & $71,2^{*}$ & $69,8^{*}$ & $69,2 *$ & $64,5^{*}$ & $50,7 *$ & $59,9 *$ & $61,3 *$ & $73,4 *$ \\
\hline $\begin{array}{l}\text { gamma-rays, } \\
250 \mathrm{~Gy}\end{array}$ & $64,6^{*}$ & $52,5^{*}$ & $61,6 *$ & $42,3 *$ & $42,5^{*}$ & $47,9 *$ & $43,8^{*}$ & $66,1^{*}$ \\
\hline
\end{tabular}

* - difference is statistically significance from check at $\mathrm{P}_{0.05}$

In general, the correlation between the dose value and survival abilities of plants is at the level of -0.9 for gamma rays. Sonechko was extremely sensitive to gamma rays. Plants of all varieties showed higher level of depression being processed with highest dose of gamma rays.

Correlation between the dose value and pollen fertility was -0.9. As we can see, the highest level of this indicator was observed after the mutagenic effect on Kolos Mironivschini seeds. Frequency of pollen sterility was on the highest level after gamma irradiation, primarily, in the varieties obtained by processing with gamma rays. Only these varieties showed extremely low fertility at a dose of 250 . Pollen sterility is the more reliable parameter for monitoring depressive consequences compared to germination and survival rates. The Table 2 shows that resistance to mutagenic effect directly depends on the genotype of processed material.

All parameters of the crop yield structure have been studied. Components such as plant height, 1000 grain weight, grain weight per plant, number of grains per spike, grain weight per spike, general number of culms, number of productive culms, spike lengths have been developed. But only three (plant height, grain weight per spike and 1000 grain weight) showed statistically difference level of mutagen depression under any dose action. Regarding the plant height, correlation between the dose and the indicator constituted - 0.89 , (high invert correlation). This parameter decreases if the dose increases. However, the differences between versions can be statistically unreliable. Gradual decrease in height is a tendency. We have not observed any differences between the varieties. The indicator of grain weight per spike was more informative, weight was falling statistically valid with every increase in dose. Here we have the same situation with the varietal specificity by depression as in the previous case. Sonechko responded to mutagenic effect in the worst manner. The correlation coefficient 
was -0.92. The thousand grain weight is the most informative indicator. Depression value at each dose is clear and statistically valid. The correlation coefficient was -0.96 .

Table3. Correlation between gamma-rays dose and some components of yield structure of $\mathrm{M}_{1}$ varieties.

\begin{tabular}{|l|l|l|l|l|l|l|l|l|}
\hline Parameter & $\begin{array}{l}\text { plant } \\
\text { height }\end{array}$ & $\begin{array}{l}\text { number } \\
\text { of } \\
\text { culms }\end{array}$ & $\begin{array}{l}\text { spike } \\
\text { lengths }\end{array}$ & $\begin{array}{l}\text { number } \\
\text { of } \\
\text { spikelets }\end{array}$ & $\begin{array}{l}\text { number } \\
\text { of } \\
\text { grains } \\
\text { per } \\
\text { spike }\end{array}$ & $\begin{array}{l}\text { grain } \\
\text { weight } \\
\text { per } \\
\text { spike }\end{array}$ & $\begin{array}{l}\text { grain } \\
\text { weight } \\
\text { per } \\
\text { plant }\end{array}$ & $\begin{array}{l}1000 \\
\text { grain } \\
\text { weight }\end{array}$ \\
\hline Dose & -0.89 & -0.34 & 0.14 & 0.12 & -0.69 & -0.92 & -0.76 & -0.96 \\
\hline
\end{tabular}

\section{Chromosomal aberrations analysis.}

The results of our investigation are represented at table 4 (total number of observing mitosis, number of division cells with chromosomal aberrations, general frequency of aberrations). Standard error $( \pm$ SE) values of the treated populations are at tables too.

As we can see from table 4 frequencies of aberrations were changed from 7,06 \% (Favoritka, gamma-rays 200 Gy) to $47,5 \%$ (Voloshkova, gamma-rays $200 \mathrm{Gr}$.) percent from total number of mitosis. All the variables are statistically significantly different from each other and from the check.

Higher frequency of aberrations in any cases characteristic for varieties obtained by breeding without using any mutagens (line 418, Kolos Mironovschiny, Voloshkova) and we can predict more rate of visible mutations (regarding previous investigations).The higher frequency of aberrations has been obtained by used 200 Gy dose. The high aberration rate was observed in Voloshkova. This variety was unstable in check too. According to the results of cluster analysis (was generated by number of chromosomal aberrations) it was found a clear determine between the method of variety obtaining and the nature of the mutagenic factor.

Identified four different groups of varieties - by using gamma rays Favoritka, Lasunya, Hurtovyna, by the action of chemical mutagens Kalinova, Sonechko and obtained using recombinant breeding - Kolos Mironovschiny, line 418 , and is entirely separate - variety Voloshkova (termomutagenesis). Thus, this method of grouping finally confirmed the conclusion that the effect of mutagenic factor is largely determined sensibility for mutagen action if these factors have used for obtained initial material. After spectra of chromosomal aberrations had been investigated next types were identified: chromosomal bridges and doublebridges, fragments of chromosomes and double-fragments, micronucleus, lagging chromosomes.

Cases with two or more types of aberrations in one cell and fragmentsbridges ratio were calculated separately. Quantity of any type of chromosomal aberrations was increased with dose increased (correlation coefficients $0,8-0,9$ ). 
Table 4. Frequency of chromosomal aberrations in $\mathrm{M}_{1}$ generation of winterwheat varieties

\begin{tabular}{|c|c|c|c|c|c|c|}
\hline \multirow{3}{*}{ Variable } & \multirow{2}{*}{$\begin{array}{l}\text { Mitosis, } \\
\text { number }\end{array}$} & \multicolumn{2}{|c|}{$\begin{array}{c}\text { Chromosomal } \\
\text { aberrations }\end{array}$} & \multirow{2}{*}{$\begin{array}{l}\text { Mitosis, } \\
\text { number }\end{array}$} & \multicolumn{2}{|c|}{$\begin{array}{c}\text { Chromosomal } \\
\text { aberrations }\end{array}$} \\
\hline & & $\mathrm{n}$. & $\%$ & & n. & $\%$ \\
\hline & \multicolumn{3}{|c|}{ Favoritka } & \multicolumn{3}{|c|}{418} \\
\hline Control & 984 & 19 & $1,93 \pm 0,31$ & 962 & 11 & $1,14 \pm 0,11$ \\
\hline Gamma-rays, 100 Gy. & 1006 & 71 & $7,06 \pm 0,74 *$ & 992 & 161 & $16,23 \pm 1,14^{*}$ \\
\hline Gamma-rays, 150 Gy & 1004 & 139 & $13,85 \pm 1,09 *$ & 1056 & 245 & $23,20 \pm 1,19^{*}$ \\
\hline Gamma-rays, 200 Gy & 943 & 230 & $24,43 \pm 1,53^{*}$ & 747 & 228 & $30,52 \pm 1,57 *$ \\
\hline \multirow[t]{2}{*}{ Gamma-rays, $250 \mathrm{~Gy}$} & 466 & 126 & $27,06 \pm 1,48 *$ & 586 & 247 & $42,15 \pm 1,89 *$ \\
\hline & \multicolumn{3}{|c|}{ Lasunya } & \multicolumn{3}{|c|}{ Hurtovina } \\
\hline Control & 1056 & 15 & $1,42 \pm 0,19$ & 1034 & 12 & $1,16 \pm 0,11$ \\
\hline Gamma-rays, 100 Gy. & 979 & 88 & $8,99 \pm 0,78 *$ & 1012 & 100 & $9,88 \pm 0,89^{*}$ \\
\hline Gamma-rays, 150 Gy & 1012 & 158 & $15,62 \pm 1,0 * 6$ & 981 & 147 & $14,99 \pm 1,03 *$ \\
\hline Gamma-rays, 200 Gy & 810 & 198 & $24,45 \pm 1,53 *$ & 1011 & 228 & $22,56 \pm 1,45^{*}$ \\
\hline \multirow[t]{2}{*}{ Gamma-rays, 250 Gy } & 399 & 98 & $24,56 \pm 1,54$ & 742 & 193 & $26,01 \pm 1,63 *$ \\
\hline & \multicolumn{3}{|c|}{ Sonechko } & \multicolumn{3}{|c|}{ Voloshkova } \\
\hline Control & 1026 & 8 & $0,78 \pm 0,04$ & 1003 & 31 & $3,09 \pm 0,34$ \\
\hline Gamma-rays, 100 Gy. & 1010 & 194 & $19,20 \pm 1,14 *$ & 1000 & 213 & $21,30 \pm 1,24 *$ \\
\hline Gamma-rays, 150 Gy & 1003 & 288 & $28,70 \pm 1,31 *$ & 1007 & 332 & $32,97 \pm 1,39 *$ \\
\hline Gamma-rays, 200 Gy & 888 & 342 & $38,51 \pm 1,85^{*}$ & 560 & 266 & $47,5 \pm 1,98^{*}$ \\
\hline \multirow[t]{2}{*}{ Gamma-rays, 250 Gy } & 411 & 190 & $46,23 \pm 2,04 *$ & 478 & 198 & $41,43 \pm 1,81 *$ \\
\hline & \multicolumn{3}{|c|}{ Kalinova } & \multicolumn{3}{|c|}{ Kolos Mironivschini } \\
\hline Control & 1047 & 9 & $0,86 \pm 0,11$ & 909 & 10 & $1,10 \pm 0,13$ \\
\hline Gamma-rays, 100 Gy. & 1000 & 192 & $19,20 \pm 1,14 *$ & 1019 & 179 & $17,56 \pm 1,04 *$ \\
\hline Gamma-rays, 150 Gy & 937 & 269 & $28,70 \pm 1,31 *$ & 890 & 215 & $24,16 \pm 1,23 *$ \\
\hline Gamma-rays, 200 Gy & 817 & 315 & $38,51 \pm 1,85^{*}$ & 738 & 243 & $32,93 \pm 1,65^{*}$ \\
\hline Gamma-rays, 250 Gy & 459 & 212 & $46,19 \pm 2,04 *$ & 510 & 196 & $38,43 \pm 1,84 *$ \\
\hline
\end{tabular}

* - difference statistically significant on $\mathrm{P}_{0,01}$

In our past investigations gamma-rays induced more bridges than fragments (fragments-bridges ratio lower than 1). After chemical mutagens more fragments have been observed (fragments-bridges ratio more than 1) (Nazarenko, 2015). We will be able to use this parameter for identify nature of unknown mutagen if it's right for other kinds of chemical mutagens. To sum it up, some authors wrote about prevalence of bridges over fragments after gamma-rays, some researchers mentioned more rates of fragments than bridges after some chemical mutagens (EMS, DMS), especially double fragments (Natarajan, 2005; Shu et al, 2011), but no one said about dominance of bridges regarding to gamma-rays. Secondly, we don't know other works about genotype-mutagen interaction on cell level 
depends on breeding methods of varieties obtaining. In our previous works we only mentioned about higher depression at $\mathbf{M}_{1}$ generation of plants when parameters of growth and development were investigated in case of mutation winter wheat variety Smuglyanka (Nazarenko, 2015). Thirdly, some aspects of mutagen-genotype interaction are well-known, but not on so deep level as changes in chromosomal aberrations rates, only as decreasing of some types of visible mutations such as dwarfness and earliness (Shu et al, 2011).

\section{CONCLUSIONS}

The most informative parameters to determine the degree of mutagenic depression in the first generation for plant growth and development were germination and survival rates. Thus, the greatest depression among all varieties was observed in Sonechko under all parameters (except thousand grains weight). Kolos Mironivschini was the most resistant to mutagenic effect. Varieties obtained by action of mutagenesis show specificity in demonstration of mutagenic depression based on the some indicators of crop yield structure.

Mutation varieties were less sensitive to same chemical mutagens. We can predict less number of mutations when these varieties would be used for mutation breeding purposes. The higher rates of chromosomal aberrations are typical for varieties obtained by used field hybridization without any mutagen treatment or when initial material for breeding has been changed by low temperature action (variety Voloshkova). Comparing between bridges and fragments is a reliable mean for identification of mutagen nature (chemical or gamma-rays). In first case more fragments have been induction, in second - bridges.

We recommended crossbreeding varieties (such as Kolos Mironovschiny) either for planting on mutagen pollution areas or as object for mutation breeding.

\section{REFERENCES}

Ahloowalia B.S., Maluszynski M., Nicoterlein K., 2004. Global impact of mutationderived varieties. In: Euphytica, 135, 187-204.

Albokari M., 2014. Induction of mutants in durum wheat using gamma irradiation. In: Pakistan Journal of Botany, 46, 317-324.

Ali Sakin M., Yildirim A., Gikmen S., 2005. Determining Some Yield and Quality Characteristics of Mutants Induced from a Durum wheat(Triticum durum Desf.) Cultivar. In: Turkean Journal Agriculture and Forestry, 29, 61-67.

Adlera, I., Carereb, A., Eichenlaub-Ritterc U., 2004. Gender differences in the induction of chromosomal aberrations and gene mutations in rodent germ cells. Environmental Research 17, 53-59.

Bignold, L.P., 2009. Mechanisms of clastogen-induced chromosomal aberrations: A critical review and description of a model based on failures of tethering of DNA strand ends to strand-breaking enzymes. Mutation Research 681, 271-298.

Grant, W.F., Owens, E.T., 2001. Chromosome aberration assays in Pisum for the study of environmental mutagens. Mutation Research 488, 93-118.

Geraskin, A.S., Dikareva, V.G., Dikareva N.S., 2002. Vliyanie razdelnogo radioaktivnogo i himicheskogo zagryazneniya na vyihod tsitogeneticheskih narusheniy $\mathrm{v}$ interkalyarnoy meristeme yarovogo yachmenya [Effect of 
separation of radioactive and chemical pollution output cytogenetic damage in intercalary meristem spring barley] Radiation Biology. Radioecology 42, 364368; (in Russian).

van Harten A.M., 1998. Mutation breeding. Theory and practical applications. Cambridge University Press, Cambridge.

Hossain M. F., Alam M. S., 2001. Effect of gamma irradiation on the callus, developed from indica rise. In: Pakistan Journal of Biological Sciences, 6, 670-671.

Huaili Q., Lanming X., Fei H., 2005. Biological effect of the seeds of Arabidopsis thaliana irradiated by $\mathrm{MeV}$ protons. In: Radiation Effects \& Defects in Solids, $160,131-136$.

Karthika I R., Subba B., 2006. Effect of Gama Rays and EMS on Two varieties of Soybean. In: Asian Journal of Biological Sciences, 5, 721-724.

Kiramat K., Muhammad I. A., 2003. Abdul Effect of Gamma Irradiation on Yield Components of Barley (Hordeum vulgare L.). In: Pakistan Journal of Biological Sciences, 19, 1695-1697.

Klekka, W.R., 1989. Diskriminantnyiy analiz. Faktornyiy, diskriminantnyiy, klasternyiy analiz [Discriminant analysis. Factorial, discriminant, cluster analysis]. Financi, Moscow (in Russian).

Korogodina, V.L., Panteleeva, A., Ganicheva, I., 1998. Vliyanie moschnosti dozyi gamma-oblucheniya na mitoz i adaptivnyiy otvet kletok pervichnyih korney prorostkov goroha [Effect of gamma irradiation on mitosis and adaptive response of cells of the primary roots of pea seedlings]. Radiation Biology. Radioecology 38, 643-649, (in Russian).

Lifang Y., Zengliang W., 2001. Radiobiological effects of a low-energy ion beam on wheat. In: Radiat Environ Biophys, 40, 53-57.

Natarajan, A.T., 2005. Chromosome aberrations: Plants to human and feulgen to FISH. Current Science 89, 335-340.

Nazarenko, M., 2015. Osobennosti vozdeystviya gamma-luchey na hromosomnyiy apparat kletki na primere pshenitsyi myagkoy ozimoy [The frequency and spectrum of chromosomal aberrations in root meristem cells of wheat under the action of mutagens]. Tambow State Unuversity Reports. Ser.: Natural and Technical sciences, 2, 449-452, (in Russian).

Nazarenko, M., 2015. Negativnyie posledstviya mutagennogo vozdeystviya [Peculiarities of negative consequences of mutagen action], Ecological Genetics, 4, 25-26. (in Russian)

Özel, H.B., Kirdar, E., Bilir, N. 2015. The effects of magnetic field on germination of the seeds of oriental beech (Fagus orientalis Lipsky.) and growth of seedlings. Agriculture and Forestry, 61 (3): 195-206

Rakhmatullina, E.M., Sanamyan M.F., 2007. Estimation of efficiency of seed irradiation by thermal neutrons for inducing chromosomal aberration in M2 of cotton Gossypium hirsutum L. Russian Journal of Genetics 43(5), 518-524.

Rank, J., Lopez, L.C., Nielsen M.H., 2002. Genotoxicity of maleic hydrazide, acridine and DEHP in Allium cepa root cells performed by two different laboratories. Hereditas 136, 13-18.

Shu, Q.Y., Forster B.P., Nakagava H., 2011 Plant Mutation breeding and Biotechnology, Vienna, CABI publishing.

Solanki I.S., Sharma B., 2000. Significance and effectiveness of classifying the M1 material based on mutagenic damage for inducing macro- and micromutations in lentil. In: Indian J. of Genetics and Plant Breeding, 60, 305-320. 
Subudhi P.K., Mohapatra B.K., Sinha S.K., 1992. Use of pollen traits for early detection of induced micromutations in wheat. In: Indian Journal of Genetics and Plant Breeding, 51, 107-111.

Yilmaz A., Erkan B., 2006. The Effects of Cobalt-60 Applications on Yield and Yield Components of Cotton (Gossipium barbadense L.). In: Pakistan Journal of Biological Sciences, 22, 2761-2769.

Ukai Y., 2006. "Effectiveness and efficiency of mutagenic treatments", In: Gamma Field Symposia, 45, pp. 1-4.

Waugha R., 2006. Harvesting the potential of induced biological diversity. In: Trends in plant Science, 11, 71-79 